\title{
Performance of Fenugreek (Trigonella foenum-graecum L.) Genotypes for Seed Yield
}

\author{
V.H. Jyothi* and R.V. Hegde \\ Department of Horticulture, College of Agriculture, Dharwad University of Agricultural \\ Sciences, Dharwad - 580 005, Karnataka, India \\ *Corresponding author
}

\section{A B S T R A C T}

\begin{tabular}{|l|}
\hline K e y w o r d s \\
Crop improvement, \\
$\begin{array}{l}\text { Fenugreek, Genotypes, } \\
\text { Germplasm, Seed yield, } \\
\text { Trigonella foenum- } \\
\text { graecum }\end{array}$ \\
\hline Article Info \\
\hline $\begin{array}{l}\text { Accepted: } \\
\text { 06 July 2018 } \\
\text { Available Online: } \\
\text { 10 August } 2018\end{array}$ \\
\hline
\end{tabular}

\section{Introduction}

Fenugreek (Trigonella foenum-graecum L.) belonging to the family Fabaceae, is an important leafy vegetable as well as an important seed spice. Because of its multifarious uses, fenugreek ranks as the third most important seed spice of India after coriander and cumin. It is a self-pollinated dicotyledonous plant with branched stems, trifoliate leaves, which bears white to yellow flowers and produces golden yellow to brown seeds. Fenugreek is a multipurpose crop being used as a spice, leafy vegetables, fodder and as a medicinal plant. The fresh tender leaves and shoots are much used as a vegetable for
The experiment was conducted in the Spice Unit, Main Agricultural Research Station, University of Agricultural Sciences, Dharwad, during Rabi 2014-15. Among the 35 genotypes evaluated, the highest plant height was recorded in DFC 5 followed by DFC 14. Maximum number of branches per plant was observed in Pusa Early Bunching. DFC 5 recorded highest number of pods per plant, pod length and pod width. DFC 11 and Ajmer Methi 2 had highest number of seeds per pod. Hundred seed weight was found to be more for Ajmer Methi 1 followed by DFC 11. DFC 22 recorded the highest seed yield per plant followed by Ajmer Methi 2. The genotypes DFC 5, Ajmer Methi 2, DFC 18 and DFC 22 proved there superiority significantly over the check Gujarat Methi 2. 
hormones and oral contraceptives. It is used in hair tonic preparations as a cosmetic. It is also important for animals, ground fine powder is mixed with cotton seed and fed to cows to increase the flow of milk. Its cultivation was mostly concentrated in Asia and the Mediterranean region, it is now widely cultivated in northern Africa, central Europe, North America and Australia (Petropoulos, 2002; Basu et al., 2014). It is a native of South Eastern Europe and West Asia and is extensively grown in India, Argentina, Bulgaria, Egypt, France, Morocco, Spain, Turkey, China, Pakistan and Lebanon. In India, fenugreek is grown in about 93,090 ha with an annual production of about $1,12,845$ tonnes. Major producing states are Rajasthan, Madhya Pradesh, Gujarat, Uttar Pradesh and Tamil Nadu. During 2012 - 2013, India earned about Rs. 10,488 lakhs foreign exchange by exporting 29,622 tonnes of fenugreek (Anon., 2014). The productivity of the crop in India is considered low, mainly due to the paucity of good high yielding varieties and inadequate access of the seed of available high yielding varieties to the growers. Keeping all these aspects in view, the present investigation was carried out with the objective to evaluate the performance of fenugreek genotypes for seed yield.

\section{Materials and Methods}

The experiment was conducted in the Spice Unit, Main Agricultural Research Station, University of Agricultural Sciences, Dharwad, during Rabi 2014-15. The experiment site is located in the agro climatic zone-VIII (Northern Transition Zone) of Karnataka state. Geographically, Dharwad is located at $15^{\circ} 26^{\prime}$ North latitude, $76^{\circ} 27^{\prime}$ East longitude and at an altitude of $678 \mathrm{~m}$ above mean sea level. Thirty five genotypes of fenugreek including check Gujarat Methi 2 obtained from different research stations and local collections were evaluated in randomized block design with two replications. Observations were recorded from five plants from the middle rows of the plot excluding the border plants, regarding various characters, namely plant height, number of branches per plant, days to $50 \%$ flowering, days to maturity, number of pods per plant, number of seeds per pod, length of pod, pod width, 100-seed weight and seed yield per hectare. The data was analysed statistically as per the methods suggested by Panse and Sukhatme (1978).

\section{Results and Discussion}

The data on different yield and yield characters of different fenugreek germplasm have been presented in Table 1 .

All characters showed a significant variation among the different germplasm. In this experiment plant height varied from $45.20 \mathrm{~cm}$ to $88.60 \mathrm{~cm}$. Among all the genotypes DFC 5 recorded highest plant height $(88.60 \mathrm{~cm})$ which was on par with DFC 14, DFC 6, DFC 22 and Ajmer Methi 1. These genotypes were significantly taller than check Gujarat Methi 2. Pusa Early Bunching was found to be the dwarf genotype recording a minimum plant height. Findings regarding the plant height and branches per plant corroborates with the findings of Bhojanagouda (2011) and Sarada and Giridhar (2011). The highest number of branches per plant was recorded in Pusa Early Bunching (15.90) followed by DFC 7, DFC 6, DFC 5 and DFC 28 which were at par with each other, which was more or less similar with the findings of Datta and Chatterjee (2004).

The genotypes showed marked differences with respect to days to $50 \%$ flowering. Among the genotypes evaluated, the genotype DFC 11 was the earliest to achieve the 50 per cent flowering stage with minimum of 35.50 days and which was on par with DFC 23, DFC 20, DFC 25 and DFC 7. 
Table.1 Per se performance of fenugreek genotypes for yield and yield attributes

\begin{tabular}{|c|c|c|c|c|c|c|c|c|c|c|c|}
\hline $\begin{array}{l}\text { SI. } \\
\text { No }\end{array}$ & Genotypes & $\begin{array}{c}\text { Plant } \\
\text { height } \\
\text { (cm) }\end{array}$ & $\begin{array}{l}\text { Number } \\
\text { of } \\
\text { branches }\end{array}$ & $\begin{array}{c}\text { Days to } \\
50 \% \\
\text { flowering }\end{array}$ & $\begin{array}{c}\text { Days to } \\
\text { maturity }\end{array}$ & $\begin{array}{l}\text { Number of } \\
\text { pods per } \\
\text { plant }\end{array}$ & $\begin{array}{l}\text { Pod } \\
\text { length } \\
\text { (cm) }\end{array}$ & $\begin{array}{c}\text { Pod } \\
\text { width } \\
(\mathbf{m m})\end{array}$ & $\begin{array}{l}\text { Numbe } \\
\text { r of } \\
\text { seeds } \\
\text { per pod }\end{array}$ & $\begin{array}{c}100 \\
\text { seed } \\
\text { weight } \\
\text { (g) }\end{array}$ & $\begin{array}{l}\text { Seed } \\
\text { yield } \\
\text { per } \\
\text { hectare } \\
\text { (q) }\end{array}$ \\
\hline 1 & DFC 1 & 66.30 & 9.40 & 47.00 & 95.50 & 39.40 & 10.91 & 3.55 & 14.58 & 2.49 & 27.64 \\
\hline 2 & DFC 2 & 73.90 & 7.40 & 40.50 & 82.50 & 44.30 & 10.22 & 3.57 & 14.20 & 1.57 & 29.48 \\
\hline 3 & DFC 3 & 71.50 & 9.10 & 45.50 & 92.00 & 28.70 & 10.89 & 3.56 & 14.12 & 1.52 & 28.96 \\
\hline 4 & DFC 4 & 78.70 & 8.40 & 41.00 & 87.50 & 41.45 & 10.46 & 3.42 & 14.96 & 1.70 & 29.85 \\
\hline 5 & DFC 5 & 88.60 & 14.00 & 39.50 & 85.50 & 55.30 & 11.48 & 4.06 & 15.64 & 1.96 & 35.78 \\
\hline 6 & DFC 6 & 84.00 & 15.45 & 42.50 & 86.00 & 46.75 & 10.56 & 3.87 & 14.36 & 1.52 & 30.55 \\
\hline 7 & DFC 7 & 72.90 & 15.70 & 38.50 & 83.00 & 35.00 & 10.22 & 3.60 & 15.14 & 1.70 & 34.48 \\
\hline 8 & DFC 8 & 80.70 & 12.20 & 42.00 & 86.00 & 37.50 & 10.67 & 3.97 & 13.90 & 2.01 & 32.00 \\
\hline 9 & DFC 9 & 61.30 & 12.10 & 44.00 & 89.00 & 29.30 & 10.62 & 3.47 & 15.10 & 1.35 & 33.25 \\
\hline 10 & DFC 10 & 78.20 & 11.90 & 42.00 & 82.50 & 37.60 & 9.15 & 3.80 & 13.92 & 1.07 & 26.54 \\
\hline 11 & DFC 11 & 69.00 & 9.90 & 35.50 & 77.00 & 21.40 & 11.11 & 3.49 & 16.18 & 2.42 & 27.58 \\
\hline 12 & DFC 12 & 76.80 & 11.60 & 46.50 & 89.50 & 36.10 & 9.62 & 3.64 & 13.66 & 1.78 & 29.63 \\
\hline 13 & DFC 13 & 69.00 & 10.90 & 40.00 & 85.50 & 40.80 & 9.78 & 3.30 & 13.34 & 1.39 & 23.51 \\
\hline 14 & DFC 14 & 85.50 & 7.30 & 44.50 & 87.50 & 32.30 & 10.45 & 3.33 & 14.04 & 1.49 & 28.10 \\
\hline 15 & DFC 15 & 78.20 & 9.30 & 41.00 & 82.00 & 43.90 & 10.21 & 3.44 & 13.55 & 1.40 & 24.68 \\
\hline 16 & DFC 16 & 73.20 & 7.90 & 39.00 & 79.50 & 44.90 & 10.55 & 3.69 & 15.10 & 1.28 & 25.48 \\
\hline 17 & DFC 17 & 58.60 & 9.60 & 43.00 & 85.50 & 25.20 & 10.51 & 3.52 & 15.26 & 1.37 & 27.16 \\
\hline 18 & DFC 18 & 79.00 & 9.10 & 41.00 & 82.50 & 50.60 & 11.02 & 3.34 & 15.54 & 1.61 & 35.25 \\
\hline 19 & DFC 19 & 68.90 & 9.60 & 44.00 & 83.50 & 37.90 & 9.17 & 3.90 & 14.02 & 1.86 & 27.96 \\
\hline 20 & DFC 20 & 67.50 & 8.70 & 37.50 & 77.00 & 41.80 & 9.90 & 3.61 & 14.04 & 1.72 & 32.58 \\
\hline 21 & DFC 21 & 75.10 & 11.60 & 45.00 & 91.50 & 29.90 & 8.32 & 3.37 & 12.48 & 1.03 & 31.15 \\
\hline 22 & DFC 22 & 82.60 & 7.25 & 40.50 & 81.50 & 51.10 & 11.17 & 3.66 & 15.40 & 1.50 & 35.08 \\
\hline 23 & DFC 23 & 61.40 & 9.30 & 37.50 & 76.50 & 39.70 & 10.63 & 3.56 & 15.10 & 1.90 & 26.30 \\
\hline 24 & DFC 24 & 67.90 & 9.80 & 39.50 & 80.50 & 33.90 & 10.29 & 3.97 & 14.72 & 1.62 & 30.76 \\
\hline 25 & DFC 25 & 67.80 & 7.90 & 38.00 & 84.00 & 51.00 & 10.42 & 3.52 & 14.72 & 2.39 & 27.86 \\
\hline 26 & DFC 26 & 71.60 & 9.40 & 41.00 & 81.00 & 38.10 & 10.75 & 3.18 & 14.82 & 1.79 & 24.40 \\
\hline 27 & DFC 27 & 61.80 & 10.60 & 46.00 & 94.50 & 44.40 & 10.42 & 3.48 & 14.56 & 1.38 & 25.85 \\
\hline 28 & DFC 28 & 67.10 & 13.90 & 42.50 & 82.00 & 43.10 & 10.07 & 3.53 & 13.98 & 1.84 & 29.25 \\
\hline 29 & DFC 29 & 69.60 & 13.00 & 41.00 & 81.50 & 31.10 & 10.81 & 3.57 & 14.64 & 1.54 & 34.35 \\
\hline 30 & Pant Ragini & 71.20 & 8.30 & 41.00 & 85.00 & 29.20 & 10.13 & 3.94 & 14.80 & 1.07 & 26.19 \\
\hline 31 & $\begin{array}{l}\text { Ajmer } \\
\text { Methi } 1\end{array}$ & 81.70 & 9.90 & 39.50 & 82.00 & 48.30 & 10.69 & 3.60 & 14.80 & 2.55 & 30.45 \\
\hline 32 & $\begin{array}{l}\text { Ajmer } \\
\text { Methi } 2\end{array}$ & 69.30 & 8.00 & 39.00 & 80.00 & 52.30 & 10.97 & 3.41 & 15.58 & 2.20 & 35.43 \\
\hline 33 & Lam M 2 & 64.60 & 9.70 & 45.00 & 93.00 & 42.70 & 9.60 & 3.57 & 14.10 & 1.94 & 26.76 \\
\hline 34 & $\begin{array}{l}\text { Pusa Early } \\
\text { Bunching }\end{array}$ & 45.20 & 15.90 & 56.00 & 109.00 & 40.50 & 8.03 & 3.54 & 13.60 & 1.11 & 20.15 \\
\hline 35 & $\begin{array}{l}\text { Gujarat } \\
\text { Methi } 2 \\
\text { (check) }\end{array}$ & 72.00 & 13.30 & 44.50 & 85.50 & 32.80 & 10.59 & 3.67 & 13.57 & 2.43 & 27.70 \\
\hline & Mean & 71.73 & 10.50 & 42.01 & 85.33 & 39.38 & 10.29 & 3.59 & 14.50 & 1.70 & 29.20 \\
\hline & $\mathrm{SEm} \pm$ & 3.99 & 1.06 & 1.64 & 2.35 & 4.39 & 0.33 & 0.08 & 0.51 & 0.23 & 2.25 \\
\hline & C.D. at $5 \%$ & 11.47 & 3.05 & 4.71 & 6.74 & 12.61 & 0.96 & 0.22 & 1.48 & 0.66 & 6.47 \\
\hline
\end{tabular}




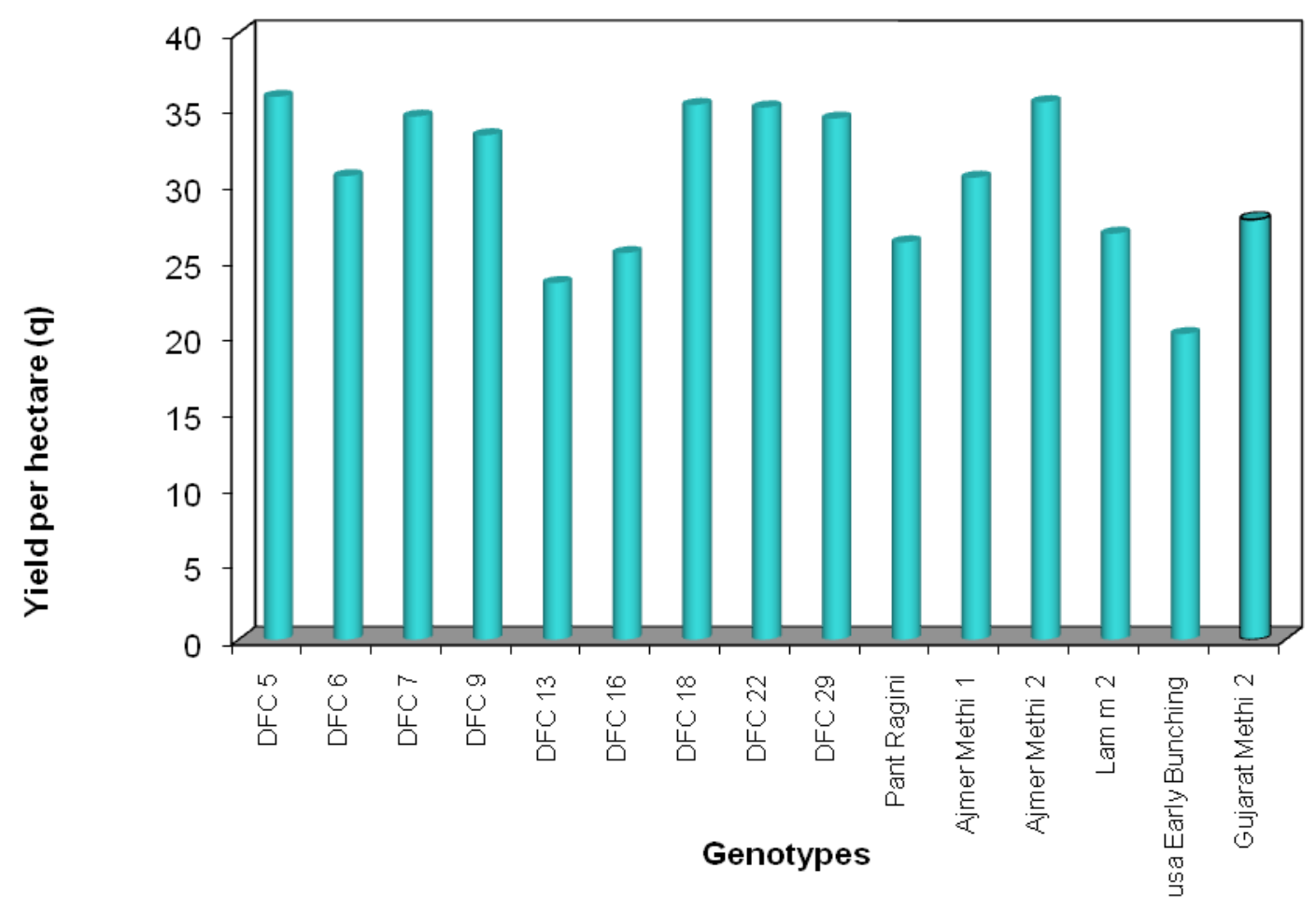

Fig. 1: Performance of fenugreek genotypes for seed yield ${ }^{f}$

Whereas, significantly maximum days to 50 $\%$ flowering was taken by Pusa Early Bunching (56.00 days). The number of days taken to maturity varied significantly among the genotypes. DFC 23 took significantly the minimum number of days (76.50) to attain maturity and was on par with DFC 20, DFC 11, DFC 16, Ajmer Methi 2, DFC 24. Whereas, significantly the maximum days to maturity was taken by Pusa Early Bunching (109.00 days). Rao (2001) evaluated diverse fenugreek genotypes in Krishna-Godavari zone of Andhra Pradesh and reported significant variation in flowering and maturity.

DFC 5 produced the highest number of pods per plant (55.30) which was on par with Ajmer Methi 2, DFC 22, DFC 25 and DFC 18 which were significantly superior to check Gujarat Methi 2 (32.80). Such increase in number of pods per plant might be due to the higher growth parameters like plant height and number of branches, contribution of increased plant height towards increased seed yield might be mainly through the production of more number of primary and secondary branches which in turn, resulted in more number of pods, as bearing area available on the plant was more (Jain et al., 2014; Verma 2002).

Significant differences in pod length and pod width was also noticed among the genotypes evaluated and pod length ranged from 8.03 $\mathrm{cm}$ to $11.48 \mathrm{~cm}$. Among all the genotypes DFC 5 registered the highest pod length $(11.48 \mathrm{~cm})$ which was on par with DFC 22, DFC 11, DFC 18 and Ajmer Methi 2 and these were higher than the check Gujarat methi 2. Significantly the highest pod width was recorded with DFC $5(4.06 \mathrm{~mm})$ which was on par with DFC 8, DFC 24 and Pant Ragini. The results are in conformity with the findings of Malik and Tehlan (2009).

Genotypes differed significantly with respect to number of seeds per pod and 100 seed 
weight. DFC 11 (16.18) recorded the highest number of seeds per pod which was on par with DFC 5, Ajmer Methi 2 and DFC 18 and these were significantly higher number of seeds per pod than check Gujarat Methi 2. The higher number of seeds per pod may be due to the higher pod length which will results in higher seed yield. The highest 100 seed weight of $2.55 \mathrm{~g}$ was recorded in Ajmer Methi 1 which was on par with DFC 1, DFC 11, DFC 25 and Ajmer Methi 2 and these were also on par with the check Gujarat Methi 2. Seeds per pod, test weight, number of pods per plant, branches per plant and plant height were the important characters for selection of high yielding lines as they exhibited direct and positive effect on seed yield per plant (Sharma and Sastry, 2008; Pushpa et al., 2012; Singh et al., 2013; Jain et al.,2014).

Significantly highest seed yield per hectare was recorded with DFC 5 (35.78 q) which was on par with Ajmer Methi 2, DFC 18, DFC 22 and DFC 7. These genotypes proved there superiority significantly over the check Gujarat Methi 2 (27.70 q). The lowest seed yield per hectare was recorded in Pusa Early Bunching (20.15 q) (Fig. 1).

The ability of a genotype to respond positively to a growing situation coupled with efficient conversion of source to sink during flowering to maturity period, which solely depends on the genotype architecture and inherent genetic potential. The higher yield is reflected by better growth and environmental conditions under which the crop is raised. Singh et al., (2006) observed that Pods per plant, number of seeds per pod, 100-seed weight and pod length are the most important traits which can respond well to selection. Malik and Tehlan (2009) evaluated diverse fenugreek genotypes under irrigated-alluvial farming situation and opined that selection of superior types improves the production in the country. Pathak et al., (2014) reported that yield traits in fenugreek differed significantly and offer a good scope for selection of better genotypes.

From the study it can concluded that the cultivation of genotypes DFC 5, Ajmer Methi 2, DFC 18 and DFC 22 may be suitable and more economical under Dharwad region. These high yielding varieties can be proposed for multi-location trials for their yield stability and further exploited in various breeding programmes for their yield potential or can be released as such after their thorough testing at various locations.

\section{References}

Anonymous, 2014. Indian Horticulture Database. www.nhb.gov.in

Basu, A., Basu, S. K., Kumar, A., Sharma, M., Chalghoumi, R., Hedi, A., Francisco, S.S., Morufat, O.B., Elsayed, E.H. and Cetzal-Ix, W., 2014. Fenugreek (Trigonella foenumGgraecum L.), A potential new crop For Latin America. American Journal of Social Issues and Humanities. 4: 145162.

Bhojanagouda, P., 2011. Evaluation of fenugreek genotypes under northern transitional belt of Karnataka. M. Sc. (Agri.) Thesis, Univ. Agric. Sci., Dharwad, Karnataka (India).

Datta, S. and Chatterjee, R., 2004. Performance of fenugreek (Trigonella foenumgraecum L.) genotypes under new alluvial zone of West Bengal. $J$. Spices Aromatic Crops. 13 (2): 132134.

Jain, N. K., Maloo, S. R. and Singh, H., 2014. On-farm performance of fenugreek (Trigonella foenum-graecum) genotypes to various fertility levels. Ann. Agri Bio Res., 19 (2): 222-223.

Malik, T. P. and Tehlan, S. K., 2009. Performance of fenugreek (Trigonella 
foenum-graecum) genotypes for growth and seed yield. Ann. of Hort., 2(2): 237 239.

Panse, V. G. and Sukhatme, P. V., 1978. Statistical Methods for Agricultural Workers, $2^{\text {nd }}$ Edn., Indian Council of Agricultural Research, New Delhi.

Patahk, A. R., Patel, A. I., Joshi, H. K. and Patel, D. A., 2014. Genetic divergence in fenugreek (Trigonella foenumgraecum L.) germplasm. Trends in Biosci., 7(4): 295-297.

Petropoulos, G.A., 2002, Fenugreek - The genus Trigonella. Taylor and Francis, London and New York. pp. 255.

Pushpa, T. N., Chandregowda, M., Srikantaprasad, D. and Gowda, A. P. M., 2012. Evaluation of fenugreek (Trigonella foenum-graecum L.) genotypes for growth and seed yield. Crop Research (Hisar). 43: 238-244.

Rao, N.H.P., 2001. Performance of fenugreek genotypes under Krishna-Godavari agro-climatic condition of Andhra Pradesh. Spice India. 14: 10-11.

Sarada, C. and Giridhar, K., 2011. Evaluation of elite fenugreek (Trigonella foenumgraecum L.) genotypes in vertisols of
Andra Pradesh. In: Spices and Aromatic plants, status and improvement. (Ed. Sastry, D. E. V., Singh, D. and Rajput, S. S.), Printer Publishers, Jaipur. pp. 175-179.

Sharma, K.C. and Sastry, E.V.D., 2008, Path analysis for seed yield and its component characters in fenugreek (Trigonella foenum-graecum L.). Journal of Spices and Aromatic Crops. 17: 69-74.

Singh, K.P., Nair, B., Jain, P.K., Naidu. A.K. and Paroha, S., 2013, Variability in the nutraceutical properties of fenugreek (Trigonella foenum-graecum L.) seeds. Revista Colombiana De Ciencias Hortícolas. 7: 228-239.

Singh, Y., Sunil, D., Sharma, S. and Sharma, A., 2006. Association of characters and their direct and indirect contribution for seed yield in fenugreek (Trigonella foenum-graecum L.). J. Res. SKUASTJ., 5(2): 191-197.

Verma, R., 2002. Evaluation of fenugreek germplasm for leaf and seed yield. M.Sc. Thesis. Dr. Y.S. Parmar Univ. of Hort. and Forestry, Nauni, Solan, Himachal Pradesh (India).

\section{How to cite this article:}

Jyothi, V.H. and Hegde, R.V. 2018. Performance of Fenugreek (Trigonella foenum-graecum L.) Genotypes for Seed Yield. Int.J.Curr.Microbiol.App.Sci. 7(08): 661-666. doi: https://doi.org/10.20546/ijcmas.2018.708.071 